\title{
Optimization of Hydrogen Production from Nigerian Crude Oil Samples Through Continuous Catalyst Regeneration (CCR) Reforming Process Using Aspen Hysys
}

\author{
Ipeghan Jonathan Otaraku*, Ishioma Laurene Egun \\ Department of Chemical Engineering, University of Port Harcourt, Port Harcourt, Nigeria \\ Email address: \\ ipeghan.otaraku@uniport.edu.ng (I. J. Otaraku), isiegun@yahoo.com (I. L. Egun) \\ ${ }^{*}$ Corresponding author
}

To cite this article:

Ipeghan Jonathan Otaraku, Ishioma Laurene Egun. Optimization of Hydrogen Production from Nigerian Crude Oil Samples Through Continuous Catalyst Regeneration (CCR) Reforming Process Using Aspen Hysys. American Journal of Applied Chemistry.

Vol. 5, No. 5, 2017, pp. 69-72. doi: 10.11648/j.ajac.20170505.11

Received: May 25, 2017; Accepted: August 21, 2017; Published: September 21, 2017

\begin{abstract}
The aim of this paper is to increase the level of hydrogen produced in the refinery from heavy treated Naphtha of Nigerian crude oil during catalytic reforming process. An existing continuous catalyst regeneration catalytic reforming process plant with four beds reactor was simulated using Aspen Hysys while treated heavy Napthene from Bonga Crude and Bonny Crude were used as feed for the process. The temperature of reactors for the process was varied between $430-540^{\circ} \mathrm{C}$ and the outlet concentrations of hydrogen (Vol.\%) produced was recorded. It was observed that an increase in temperature lead to an increase in the concentration of hydrogen produced as the volume of hydrogen at $430^{\circ} \mathrm{C}$ was $23.46 \%$ volume while at $540^{\circ} \mathrm{C}$ it was $51.38 \%$ volume showing a significant increase in the aromatic yield level. The results also showed that the naphthene content of feed affects the volume of hydrogen produced which made Bonga crude a better source for hydrogen when compared with Bonny crude.
\end{abstract}

Keywords: Hydrogen Yield, Bonga Crude, Bonny Crude, Catalytic Reforming, Naphthene, Temperature

\section{Introduction}

In a country like Nigeria, the need to increase the availability of Hydrogen $\left(\mathrm{H}_{2}\right)$ cannot be underestimated as it is one of the gases needed in various aspects of life. Large quantities of are needed in the petroleum and chemical industries. The largest application of $\mathrm{H}_{2}$ is for the processing ("upgrading") of fossil fuels, and in the production of ammonia [1]. Hydrogen production through steam reforming of biomass-derived compounds has shown that it is an economically feasible and environmental way to efficiently use renewable energy resources. The search for more efficient strategies to produce hydrogen from bio-derived aqueous phases as an environmentally friendly strategy to power diverse energy needs is still on [2].

Currently the level of hydrogen produced is not enough to meet the industry need, therefore there is need to optimize the production from the most predominant industry process which is the catalytic reforming process. For small scale hydrogen plants, air-blown catalytic partial oxidation coupled with membrane separation may be a preferred route [3]. There is a growing need for hydrogen. Hydrogen will play a key role in the manufacture of better transportation fuels. It may also play a role in the introduction of a "hydrogen economy". The conversion of hydrocarbons is the most economic route to hydrogen [4].

\section{The Process}

Catalytic reforming is a process for producing high octane gasoline blending component as main products with hydrogen and liquefied petroleum gas as by-products from heavy naphthene [5]. Catalytic reforming is a vital in the refinery processes, because it leads to the production of highoctane components and hydrogen which is highly demanded in other refinery units like hydrotreaters [6]. The significance of this industrial process has made researchers to investigate different aspects of catalytic reforming process intensively 
[5]. Most naphtha reforming processes usually takes place in three or four fixed bed reactors which operate adiabatically at temperatures between 450 and $520^{\circ} \mathrm{C}$, total pressures between 10 and 35 bar, and molar hydrogen-to hydrocarbon ratios between 3 and 8 [7]. "Figure 1" below shows the process flow diagram of the catalytic reforming process.

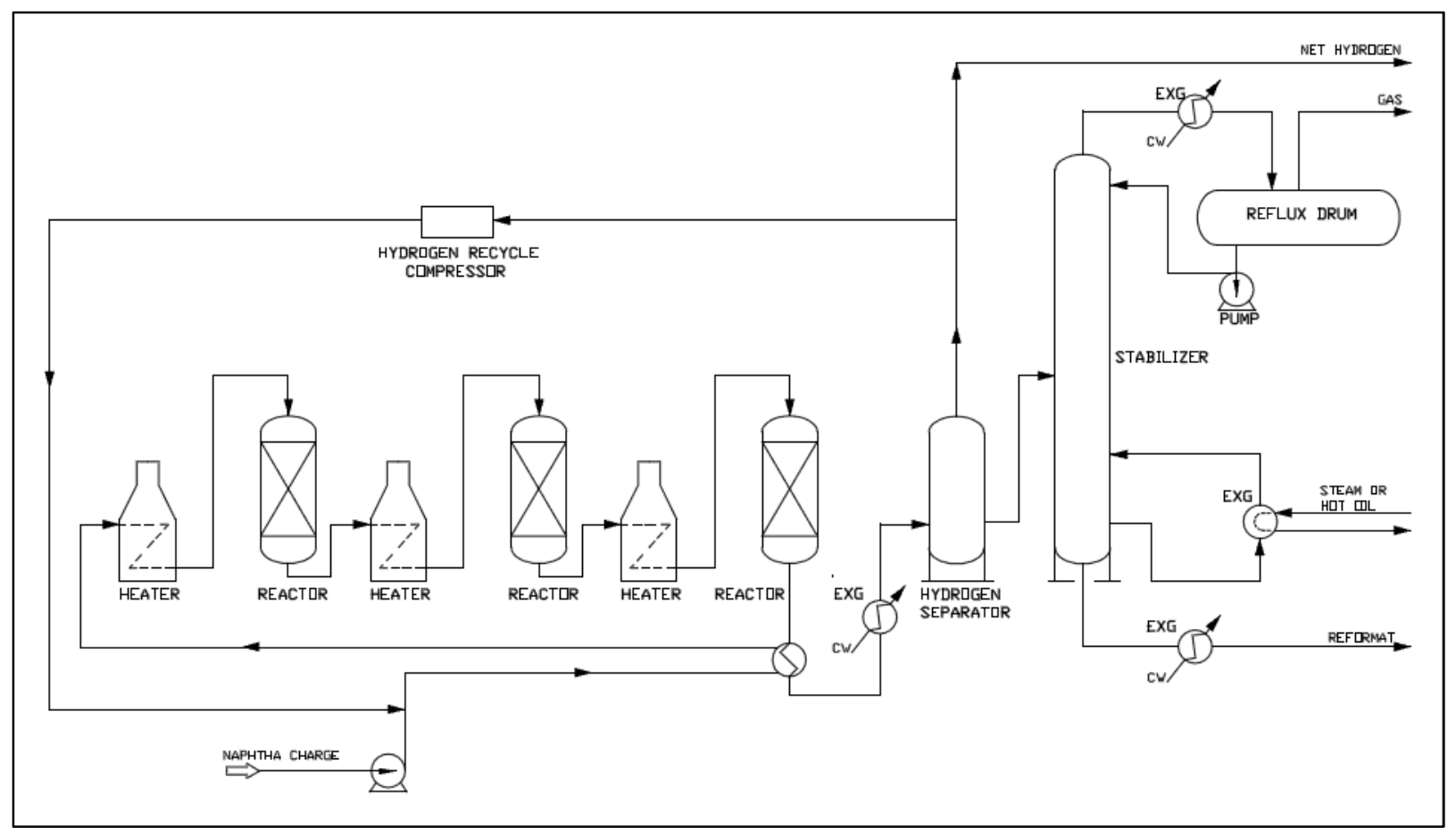

Figure 1. Schematic Representation of Continuous Catalytic Regeneration [7].

The advantages of Continuous Catalytic Reforming process include: Production of higher octane reformate despite feed quality, long time working of the process to increase hydrogen produced, using catalyst with higher selectivity and yield, low recycle ratio and the low pressure involved during operation with high yield of hydrogen [8].

The feed for the catalytic reformer is usually heavy treated Naphthene. For this work, heavy treated Naphthene from Bonga Aromatic and Forcados were chosen.

Bonga Aromatic crude is a medium gravity, low sulphur, naphthenic crude. It is similar in quality and yield pattern to Forcados, though slightly heavier [9].

Bonny Light: Bonny light is a high quality of Nigerian crude oil with high American Petroleum Institute (API) gravity (low specific gravity). It is mainly gotten in the Niger Delta region of Nigeria and it is named after the city of Bonny in Rivers State [10].

\subsection{The Simulation}

The catalytic reformer was modeled in a steady state mode using catalytic reformer template of ASPEN Hysys 7.2. In setting up the model, the fluid property package was chosen to be Peng-Robinson and the reactors configured as 4 beds.

Figure 2 is the catalytic reformer template configured with four bed reactors for the reforming process in the Hysys environment.

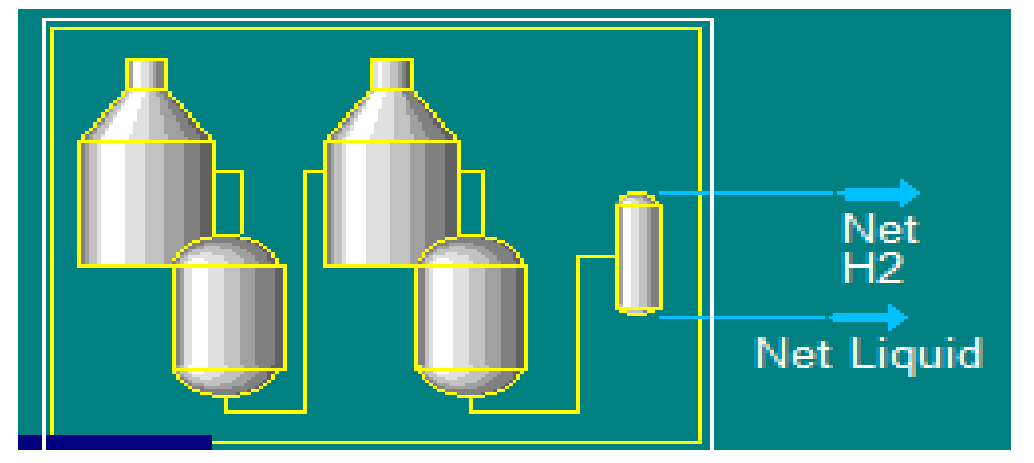

Figure 2. Window showing reactor section of catalytic reformer template in the Hysys environment.

The feed and other input values used for modeling the catalytic reformer are given in Table 1 below
Sample 1: Bonga Crude

Sample 2: Bonny light Crude 
Table 1. Bonga Crude Assay [9].

\begin{tabular}{ll}
\hline Crude & Heavy Naptha \\
\hline Density at $15^{\circ} \mathrm{C}: 879.5 \mathrm{~kg} / \mathrm{m}^{3}$ & Density at $15^{\circ} \mathrm{C}: 761 \mathrm{~kg} / \mathrm{m}^{3}$ \\
Nitrogen ppm 1219.9 & Cut ${ }^{\circ} \mathrm{C} 80-160$ \\
Sulphur wt $\% 0.24863$ & Yield 13.97 Vol.\% \\
API 29.4 & Napthene 60.59 Vol. $\%$ \\
& Paraffin 25.53 Vol.\% \\
& Aromatics 13.88 Vol.\% \\
\hline
\end{tabular}

Table 2. Bonny Light Crude Assay [10].

\begin{tabular}{ll}
\hline Crude & Heavy Naphtha \\
\hline Density at $15^{\circ} \mathrm{C} 854.8 \mathrm{~kg} / \mathrm{m}^{3}$ & Density at $15^{\circ} \mathrm{C} 780.0 \mathrm{~kg} / \mathrm{m}^{3}$ \\
Nitrogren $\mathrm{wt} \% 0.220$ & Cut $80-160^{\circ} \mathrm{C}$ \\
Sulphur $\mathrm{m} / \mathrm{m} \% 0.16$ & Yield $18.72 \mathrm{Vol} \%$ \\
API 34 & Napthene $50.6 \mathrm{Vol} \%$ \\
& Paraffin 33.7 Vol.\% \\
& Aromatics $15.7 \mathrm{Vol} \%$ \\
\hline
\end{tabular}

\subsection{Kinetic Model}

The kinetic model used in the catalytic reformer template was that of Smith's which considers the following reaction: Dehydrogenation of naphthenes to aromatics, Dehydrocyclization of paraffins to naphthenes, Hydrocracking of naphthenes to light ends and Hydrocracking of paraffins to light ends

The kinetics, as described in [11], is written as:

$$
\begin{aligned}
& N \leftrightarrow A+3 \mathrm{H}_{2} \\
& P \leftrightarrow N+\mathrm{H}_{2} \\
& N+2 \mathrm{H}_{2} \leftrightarrow 2 G \\
& P+\mathrm{H}_{2} \leftrightarrow 2 G
\end{aligned}
$$

Where N, A, G, H and P; are Naphthenes, Aromatics, Gases, Hydrogen and Paraffin respectively.

The Arrhenius type of rate expression is assumed for the reactions to occur:

$$
\mathrm{kf}=k o f e^{\left(\frac{-E f}{R T}\right)}
$$

The activation energy $\mathrm{E}$ is dependent on the catalyst and $\mathrm{k}_{\mathrm{o}} \mathrm{f}$ is dependent on the molarity of the reaction $\mathrm{R}$ is the universal gas constant [11]. Dehydrogenation reaction which is endothermic dominates the entire reactions thereby causing significant change in the temperature of the reactant [12]. To maximize the production level of hydrogen "(1)" and "(2)" should be optimized (dehydrogenation of naphthenes and the dehydrocyclization of paraffins produce hydrogen).

\section{Results and Discussion}

The result obtained from the simulation is shown below:

Table 3. Total Hydrogen Yield Results.

\begin{tabular}{lll}
\hline Temperature & Samples (Vol.\%) & \\
\hline T x 100 & Sample 1 & Sample 2 \\
4.3 & 0.6 & 0.46 \\
4.4 & 0.77 & 0.61 \\
4.5 & 0.94 & 0.76 \\
4.6 & 1.12 & 0.93 \\
4.7 & 1.32 & 1.10 \\
4.8 & 1.53 & 1.29 \\
4.9 & 1.74 & 1.47 \\
5.0 & 1.97 & 1.66 \\
5.1 & 2.03 & 1.85 \\
5.2 & 2.17 & 1.97 \\
5.3 & 2.32 & 2.10 \\
5.4 & 2.47 & 2.24 \\
\hline
\end{tabular}

The volume of hydrogen yield of the samples at various temperature changes for the reactor is shown in Table 3 above. As the temperature increases, the volume of hydrogen produced increases. From the simulation result, it is seen that at higher temperature there is increase in the hydrogen yield which is good for other refinery units.

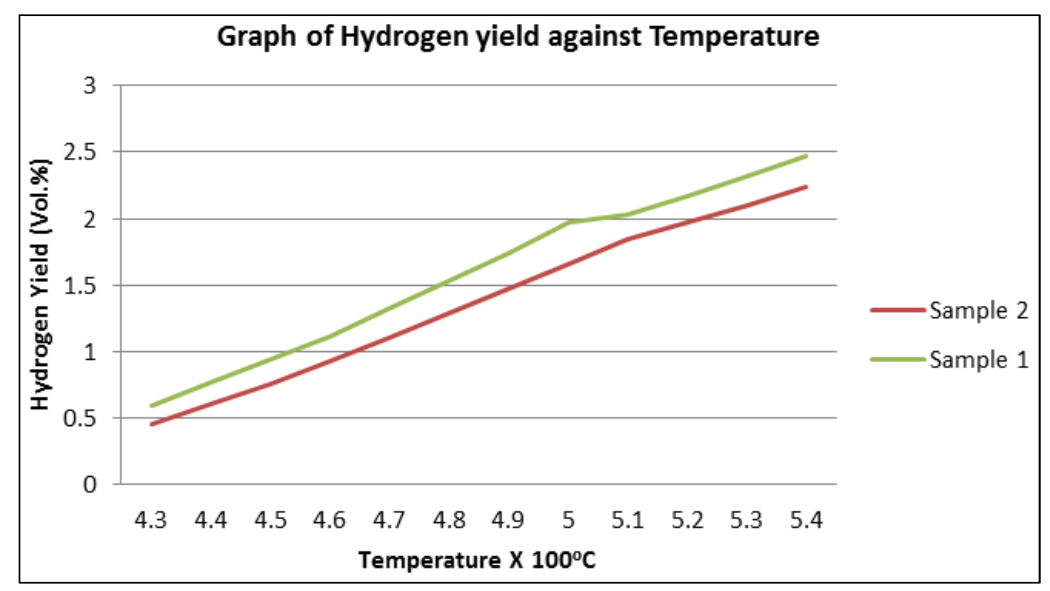

Figure 3. The effect of Temperature on Hydrogen yield.

From Figure 3 above, it is seen that the curves are linear; showing that as the temperature increases the hydrogen yield increases, showing a linear relationship between temperature and hydrogen yield. Therefore to increase the level of hydrogen produced in an existing refinery, the temperature of the catalytic reforming process will be increased.

From the table above it is seen that sample 1 gave a higher level of hydrogen yield when compared to sample 2. The 
temperature increase leads to higher yields of hydrogen and less amount of light carbons in agreement with literature [13]. Also, the significant difference in naphthene composition of both samples played a part in the level of hydrogen produced as the reaction responsible for hydrogen production is dependent on the naphthene composition.

\section{Conclusion}

1. The operating temperature of the continuous catalyst regeneration (CCR) reforming process affects the volume of hydrogen produced. At $440^{\circ} \mathrm{C}$ the yield of hydrogen for the two samples was about $0.6 \%$ by volume whereas at $540^{\circ} \mathrm{C}$ the yield was above $2 \%$ by volume. The endothermic nature of dehydrogenation and dehydrocyclization are favoured at high temperatures. Limitation will be imposed by material of construction of the reactors.

2. The naphthene content of the reforming feed affects the hydrogen yield. The higher the naphthene content, the more the hydrogen yield. Stability and susceptibility of naphthene to form cyclic compounds increases the hygrogen formation.

3 . In order to maximize the production of hydrogen in a catalytic reformer the process temperature should be considered. Using Le Chatelier's Principle, higher temperatures will favour higher hydrogen yield. However, the value of the temperature has to be a compromise between reactor materials and economy of the quantity of hydrogen yield viz-a-viz the cost of high temperature operations and environmental impact. Also, catalytic stability at higher temperatures is a limiting factor.

\section{References}

[1] Chemistry Operations (15 December 2003). "Hydrogen", Los Alamos National Laboratory, Retrieved 5 February 2008.
[2] Donghai Mei et al. Steam Reforming of Ethylene Glycol over MgAlO Supported Rh, Ni, and Co Catalysts, ACS Catalysis (2016). DOI: 10.1021/acscatal.5b01666.

[3] Rostrup-Nielsen, J. R. Phys. Chem. Chem. Phys, 3 (2001) 283.

[4] Jens R. Rostrup-Nielsen and Thomas Rostrup-Nielsen, Largescale Hydrogen Production, CATTECH (2002) 6: 150. doi: 10.1023/A:1020163012266.

[5] Zaidoon M. S., Optimization of Al-Doura Catalytic Naphtha Reforming Process Using Genetic Algorithm, Eng. \&Tech. Journal Vol. 31, 2013, Part A, No. 7.

[6] Shuichi K., Analysis of catalytic reforming characteristics of various Hydrocarbons, JSAE Annual congress No. 43-04, 2004.

[7] Mohan L., Catalytic Reforming Process, Catalysts and Reactors 6th Summer School on Petroleum Refining \& Petrochemicals Indian Institute of Petroleum Management Gurgaon, 2011, June 6-10.

[8] Mohammad, R. R., Mitra J. and Davood I. (2013): "Progress in catalytic naphtha reforming process". Applied Energy 109 79-93.

[9] Exxon Mobil (2016): www.exxonmobilng.com

[10] Chevron (2016): www.chevronng.com

[11] Wordu, A. A., Dynamic Simulation of Industrial Reformer Reactors, International Journal of Engineering and Technology Volume 2 No. 7, July ISSN: 2049-3444, 2012 IJET Publications UK.

[12] Chang A. F, Kiran P., Y. A. Liu (2012): Refinery Engineering, Integrated Process Modeling and Optimization, Wiley-VCH Verlag GmBH and Co. KGaA, Boschstr., 12.69469 Weinheim, Germany.

[13] $\mathrm{Hu}$ S. and Zhu X. X. (2004): Molecular Modeling and Optimization for Catalytic Reforming. Journal of Chemical Engineering Communications, Vol. 191, No. 4, pp 500-512 (13). 